\title{
New genus of the tribe Ceutorhynchini (Coleoptera: Curculionidae) from the late Oligocene of Enspel, southwestern Germany, with a remark on the role of weevils in the ancient food web
}

\author{
Andrei A. Legalov ${ }^{1,2}$ and Markus J. Poschmann ${ }^{3}$ \\ ${ }^{1}$ Institute of Systematics and Ecology of Animals, Siberian Branch, Russian Academy of Sciences, Frunze Street, 11, \\ Novosibirsk 630091, Russia \\ ${ }^{2}$ Altai State University, Lenina 61, Barnaul 656049, Russia \\ ${ }^{3}$ Generaldirektion Kulturelles Erbe RLP, Direktion Landesarchäologie/Erdgeschichte, Niederberger Höhe 1, \\ 56077 Koblenz, Germany
}

Correspondence: Andrei A. Legalov (fossilweevils@gmail.com)

Received: 10 September 2020 - Revised: 19 October 2020 - Accepted: 20 October 2020 - Published: 23 November 2020

\begin{abstract}
The new weevil genus Igneonasus gen. nov. (type species: I. rudolphi sp. nov.) of the tribe Ceutorhynchini (Curculionidae: Conoderinae: Ceutorhynchitae) is described from the late Oligocene of Fossillagerstätte Enspel, Germany. The new genus differs from the similar genus Stenocarus Thomson, 1859 in the anterior margin of the pronotum, which is not raised, a pronotum without tubercles on the sides, and a femur without teeth. This weevil is the largest representative of this supertribe and the first fossil Curculionidae species described from the paleolake Enspel. In this ancient ecosystem, weevils were at least sometimes an important food resource for the cyprinid fish Palaeorutilus enspelensis.
\end{abstract}

\section{Introduction}

Oligocene weevils are studied less well than other Paleogene Curculionoidea faunas and hitherto comprised 94 described species (Legalov, 2020b). Curculionoidea are reported from 19 localities, but many of them still await description. Currently, 72 Oligocene species of the family Curculionidae are known and are assigned to the subfamilies Erirhininae, Molytinae, Lixinae, Dryophthorinae, Cossoninae, Conoderinae, Curculioninae, and Entiminae (Legalov, 2020b). Five Oligocene weevil localities (the early Oligocene locality Seifhennersdorf, the middle Oligocene localities Sieblos and Kleinkembs, and the late Oligocene localities Enspel and Rott) are situated in Germany (Legalov, 2015, 2020b). Nineteen species of Curculionidae are described from Sieblos, Kleinkembs, and Rott (Legalov, 2020b). The weevils from Enspel are often particularly well-preserved with chitin still present in their exoskeleton (Stankiewicz et al., 1997). Some specimens from Enspel have been previously figured (Wedmann, 2000; Wedmann et al., 2010; Penney and Jepson, 2014), but a detailed taxonomic approach was still lacking.

Here we describe a new fossil genus and species of the supertribe Ceutorhynchitae belonging to the tribe Ceutorhynchini.

\section{Locality}

The black pelitic sediments or "oil shales" of Fossillagerstätte Enspel were deposited in a deep meromictic and eutrophic crater lake of the High Westerwald (Pirrung et al., 2001; Schindler and Wuttke, 2010, 2015). In a $140 \mathrm{~m}$ thick sedimentary sequence, oil shales alternate with fallout tuffs, tuffites, turbidites, and debris flows (Gaupp and Wilke, 1998; Felder et al., 1998; Schindler and Wuttke, 2010, 2015). The existence of the paleolake Enspel was suddenly terminated by a lava flow originating from a nearby volcano and covering it with about $100 \mathrm{~m}$ of basaltic lava (Schindler and Wuttke, 2010).

Fossillagerstätte Enspel has an excellent age constraint, biostratigraphically based on the appearance of the eomyid rodent Eomys quercyi Comte and Vianey-Liaud, 1987 indi- 
cating the late Oligocene mammal zone MP28 and an absolute age of 28.4-23.0 mya (Storch et al., 1996; Engesser and Storch, 1999). Dating of basalts both pre- and postdating lake sedimentation yielded a more accurate radioisotopic age of 24.9-24.5 mya for the MP28 level at Enspel (Mertz et al., 2007). For further details about the geology see Schindler and Wuttke (2010, 2015) and Schäfer et al. (2011).

The youngest part of the lake sediments was subject to annual scientific excavation conducted by the GDKE RLP, Direktion Landesarchäologie/Erdgeschichte from 1990 until 2015 and yielded rich taphocoenoses including bacteria (or melanosomes); various microfossils; macroplants; sponges; vertebrates such as fishes, crocodiles, amphibians, birds, and mammals (see e.g. overview by Poschmann et al., 2010; Wuttke et al., 2010, 2015; Köhler and Uhl, 2014); and more than 12000 specimens of arthropods, mainly insects and a minor share of arachnids (e.g. Wedmann, 1998a, b, 2000; Poschmann and Wedmann, 2005; Poschmann, 2006; Wappler and Heiss, 2006; Fikáček et al., 2008; Wedmann et al., 2010; Fanti and Poschmann, 2019; Brockhaus et al., 2020; Jessen, 2020).

\section{Material and methods}

The material studied here is part of the Landessammlung für Naturkunde Rheinland-Pfalz at the Naturhistorisches Museum Mainz. Specimens were photographed immersed in water using a Leica DFC 420 digital camera attached to a Leica MZ 7.5 stereomicroscope (Figs. 1, 3c). In order to enhance depth of field, multiple images at differing focal planes were taken and combined into a composite using LAS V2.7 image stacking software (by Leica Microsystems). Figure 3a-b were taken using a Canon EOS 600D SLR camera equipped with a Canon EFS $60 \mathrm{~mm}$ macro lens, and image stacking software CombineZP (by Alan Hadley) was used to enhance depth of field.

The morphological terminology used in this paper follows Lawrence et al. (2010).

Nomenclatural acts introduced in the present work are registered in ZooBank (http://www.zoobank.org, last access: 19 November 2020) under LSID urn:lsid:zoobank.org:pub:1760D86D-05E6-454F-A1E02E6D7450380D.

\section{Systematic paleontology}

Family: Curculionidae Latreille, 1802

Subfamily: Conoderinae Schoenherr, 1833

Supertribe: Ceutorhynchitae Gistel, 1848

Tribe: Ceutorhynchini Gistel, 1848

\author{
Genus Igneonasus gen. nov. \\ urn:1sid:zoobank.org:act:CE2FAC7D-C476-464A- \\ A4C1-C7C2EEFEE665
}

\section{Type species}

I. rudolphi sp. nov., herein designated.

\section{Etymology}

The generic name is derived from the Latin igneo for fire, with respect to the volcanic origin and destruction of the paleolake Enspel, and nasus for nose. Gender masculine.

\section{Diagnosis}

Large beetle; body black, strongly chitinized; rostrum longer than pronotum, rather thick, curved; antennal scrobes lateral; forehead flattened; antennae inserted in apical third of rostrum; anterior margin of pronotum not raised; pronotum with longitudinal median sulcus; sides without tubercles; elytra plump with convex humeri; striae regular; interstriae very wide; prosternum and mesoventrite with rostral channel; postocular lobes present; precoxal portion of prosternum elongated; mesepimeron strongly ascending; abdomen convex ventrally; ventrites 1 and 2 elongated; ventrites 3 and 4 short; pygidium convex, exposed beyond elytra; legs long; procoxae subconical; femora weakly clavate, without teeth; tibiae almost straight, without uncus; tarsomeres 1 and 2 conical.

\section{Comparison}

The new genus can be compared with the genus Stenocarus C.G. Thomson, 1859 because of the rather thick rostrum and mesoventrite with the rostral channel but differs in the non-raised anterior margin of the pronotum, the pronotum without tubercles on the sides, and the femur without teeth. Its large body size $(7.8 \mathrm{~mm})$ makes the new genus the largest known Ceutorhynchitae. Previously, the largest were species of the genus Mogulones Reitter, 1916 with a maximum length $(6.4 \mathrm{~mm})$ and Mononychus Germar, 1823 with $6.0 \mathrm{~mm}$ (Arnoldi et al., 1965; Gültekin and Colonnelli, 2006). The new genus differs from the genus Mogulones in the nonraised anterior margin of the pronotum, rather thick rostrum, mesoventrite with the rostral channel, and the femur without teeth. Mononychus differs from other Ceutorhynchitae genera in the one tarsal claw (Colonnelli, 2004; Legalov, 2018), but the structure of the claws in the new genus is not known. The new genus is distinguished from this genus in the rather thick rostrum with subapically inserted antennae and mesoventrite with rostral channel. The genus Phrydiuchus Gozis, 1885 also has a rather thick rostrum. The new genus differs from Phrydiuchus in a rostrum narrower than profemora, non-raised anterior margin of the pronotum, pronotum without lateral tubercles, mesoventrite with rostral chan- 


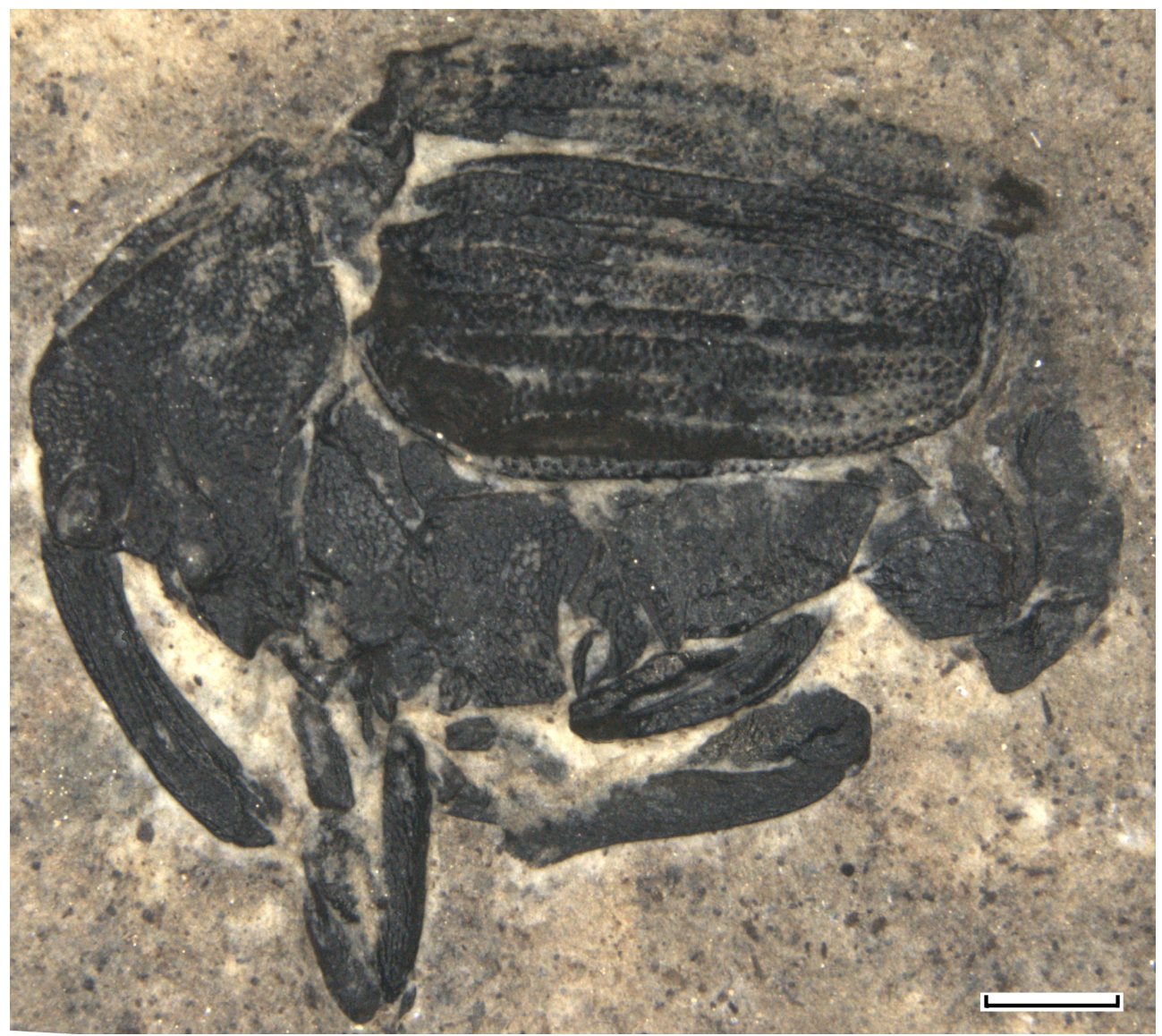

Figure 1. Igneonasus rudolphi gen. et sp. nov., holotype PE 2013/5017-LS, habitus, lateral view. Scale bar $=1.0 \mathrm{~mm}$.

nel and large body size. An interesting character is the nonraised anterior margin of the pronotum, which is present in some genera (Datonychus Wagner, 1944, Tapinotus Schoenherr, 1826) with quite large species. The new genus differs from Datonychus in the thicker rostrum, mesoventrite with rostral channel, the pronotum without tubercles, femora without teeth, and larger body size. It differs from Tapinotus of the tribe Scleropterini in the thinner rostrum with subapical inserted antennae, wide pronotum, non-elongated elytra, mesoventrite with rostral channel, and femora without teeth.

\section{Remarks}

The strongly ascending mesepimeron suggests placement in the subfamily Conoderinae. Placement of the fossil genus in the subtribe Ceutorhynchitae is based on the rounded plump body, unarmed tibiae, exposed pygidium, and long ventrites 1 and 2 , where ventrite 1 is longer than ventrite 2 . The new genus belongs to the tribe Ceutorhynchini based on the long precoxal portion of the prosternum, a distinctly long rostrum, which is narrower than width of the profemur, and metafemora not thicker than other femora.
Igneonasus rudolphi gen. et sp. nov. urn:Isid:zoobank.org:act:6BDF0F29-C03F-46FD86F1-337D9A94F171

Figs. 1-2

\section{Etymology}

The specific epithet is for Martin Rudolph (Westerburg) and his engagement at the Stöffel-Park and Fossillagerstätte Enspel.

\section{Type material}

Holotype: specimen PE 2013/5017-LS, deposited in the Landessammlung für Naturkunde Rheinland-Pfalz.

\section{Type locality and stratum}

Enspel/Westerwald, Germany. Late Oligocene Enspel Formation sensu Schäfer et al. (2011).

\section{Description}

Size: length of body (without rostrum), $7.8 \mathrm{~mm}$; length of rostrum, $2.6 \mathrm{~mm}$. Body black. 


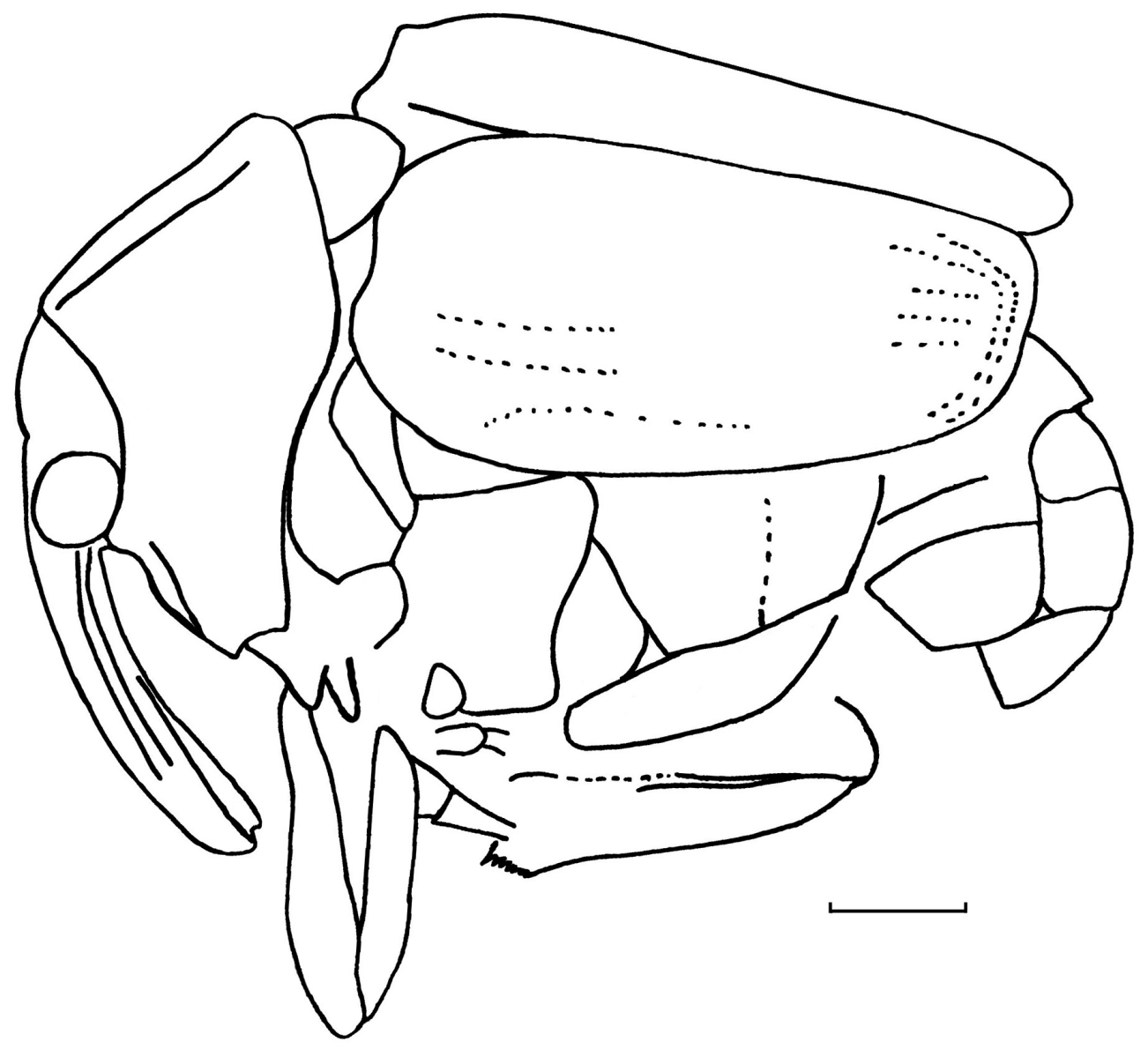

Figure 2. Igneonasus rudolphi gen. et sp. nov., holotype PE 2013/5017-LS, contour of body, lateral view. Scale bar $=1.0 \mathrm{~mm}$.

Head: rostrum long, 1.2 times as long as pronotum, 8.1 times as long as wide at apex, 7.2 times as long as wide in middle, 5.0 times as long as wide at base, subcylindrical, distinctly curved, densely punctate, not separated from head by transverse impression; antennal scrobes lateral and directed toward ventral margin of eye; forehead flattened, punctured; eyes large, rounded, 1.2 times as long as wide, slightly wider than rostrum base wide; vertex weakly convex, densely punctate; temples 0.5 times as long as eye length; antennae inserted in apical third of rostrum.

Pronotum: bell-shaped; transverse; anterior margin of pronotum not raised; disc weakly convex in basal half, narrowed at apex, densely punctuate, with longitudinal median sulcus; distance between points distinctly less than diameter of points; sides coarsely punctuate, without tubercles; scutellum almost triangular, flattened, punctate.

Elytra: plumb, weakly flattened, 1.8 times as long as pronotum; elytron 2.4 times as long as wide at base, 2.0 times as long as wide in middle, 3.1 times as long as wide at apical fourth; greatest width in humeri, elytral base wider than pronotum base wide; humeri convex; striae regular, deep, narrow; interstriae flattened, wide, 7.0-9.0 times as wide as striae, punctuate; apex of each elytron rounded.

Thorax: coarsely punctured; prosternum with distinct median rostral channel; postocular lobes present; precoxal portion of prosternum elongated, about 2.2 times as long as procoxal length; postcoxal portion of prosternum short; mesoventrite with rostral channel; mesepimeron strongly ascending; metaventrite subequal to metacoxal length; metepisternum wide at base, further narrow, 2.7 times as long as wide at base, 12.5 times as long as wide in middle.

Abdomen: convex ventrally, coarsely punctured, distance between points longer than diameter of points; ventrites 1 and 2 elongated, fused; ventrite $1,1.3$ times as long as metacoxa length; ventrite 2, 0.6 times as long as ventrite 1 ; ventrites 3 and 4 short; ventrite 4, 0.6 times as long as ventrite 2; ventrite 5, 2.4 times as long as ventrite 4 . Pygidium convex, exposed beyond elytra.

Legs: legs long; procoxae subconical; metacoxae transverse; femora weakly clavate, without teeth; profemora 4.7 times as long as wide in middle; wide of profemora 1.5 times as long as wide of rostrum in middle; metafemora not thicker than other femora; tibiae quite wide, almost straight, without 

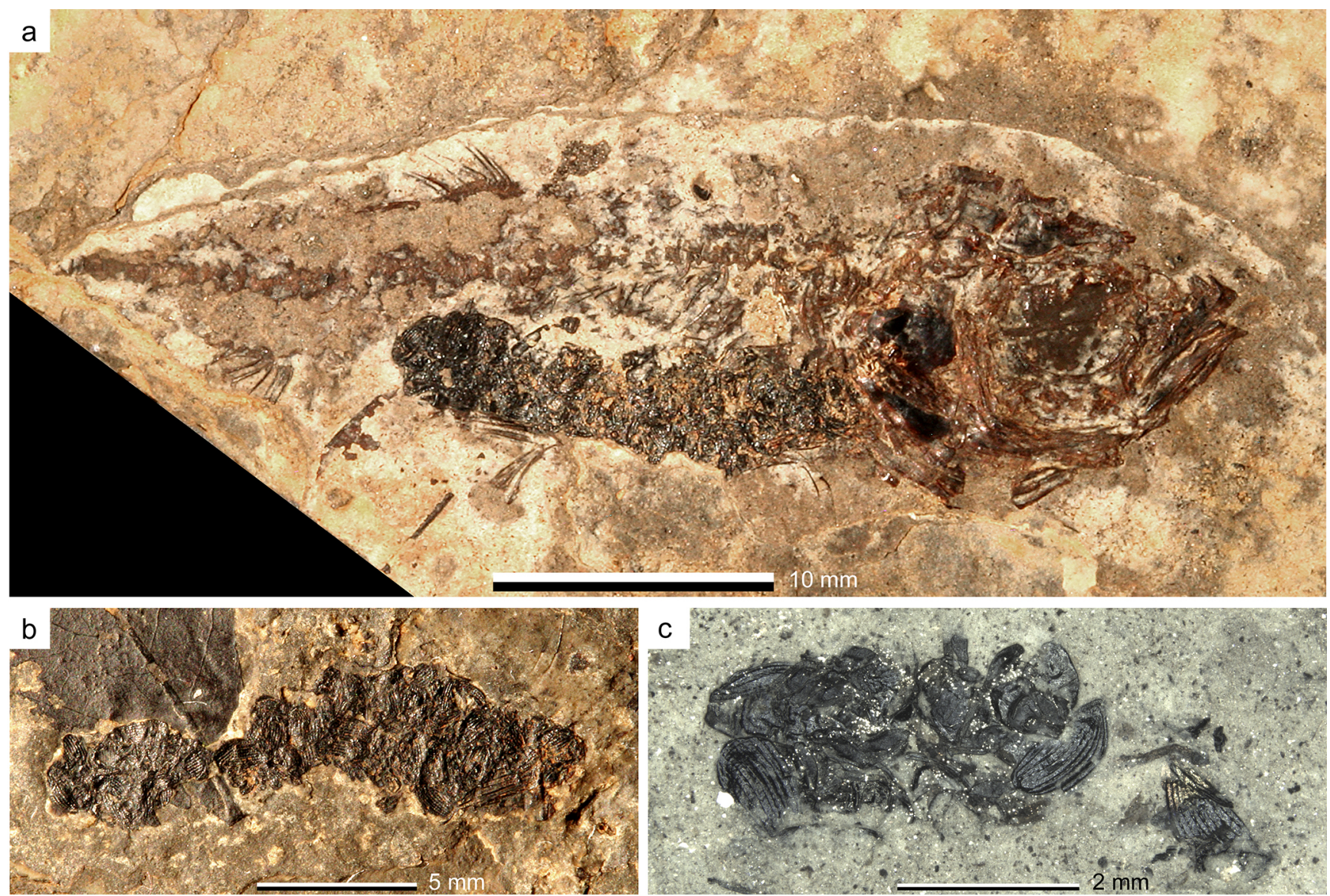

Figure 3. (a) Cyprinid fish Palaeorutilus enspelensis (Böhme, 1996) with digestive tract filled with weevil elytra, specimen PW 2011/5743LS a; (b) digestive tract of counterpart specimen enlarged, PW 2011/5743-LS b; (c) coprolite made of small weevil elytra, supposedly produced by Palaeorutilus, specimen PE 2014/5144-LS.

uncus; protibiae 5.7 times as long as wide in middle; metatibiae 5.5 times as long as wide in middle; tarsi long; tarsomeres 1 and 2 conical; mesotarsomere $1,1.6$ times as long as wide; metatarsomere $1,1.7$ times as long as wide at apex.

\section{Discussion}

The supertribe Ceutorhynchitae is a diverse group of the subfamily Conoderinae (Zherikhin and Egorov, 1991; Oberprieler et al., 2007; Prena et al., 2014; Legalov, 2015, 2018; Alonso-Zarazaga et al., 2017). It is also considered as an independent subfamily (Alonso-Zarazaga and Lyal, 1999; Anderson, 2002; Colonnelli, 2004; Hacet and Colonnelli, 2019) or part of the subfamily Curculioninae (Marvaldi and Lanteri, 2005). More than 1300 species from 175 genera are known in the recent fauna (Prena et al., 2014). The suprageneric structure is represented by 11 tribes (Colonnelli, 2004; Legalov, 2018). The oldest representative of this supertribe is known from the early Eocene of England (Cockerell, 1920), but since it is described by the elytron, its systematic position needs to be clarified (Legalov, 2015). The earliest reliable species of the tribe Ceutorhynchini, provisionally placed in the genus Ceutorhynchus Germar, 1823, is described from the early-middle Eocene of Green River Formation (Scudder, 1893; Legalov, 2015). Three species of the genus Ceutorhynchus and Baltocoeliodes sontagae Legalov \& Bukejs, 2018 from the tribe Ceutorhynchini are described (Legalov, 2013, 2016, 2020a; Legalov and Bukejs, 2018), and one species of the genus Rhinoncus Schoenherr, 1825 (Phytobiini) is recorded from the middle-upper Eocene Baltic amber (Klebs, 1910). The most ancient Cnemogonini and four species of Ceutorhynchini are found in the terminal Eocene of Florissant (Scudder, 1893; Wickham, 1916; Legalov, 2015). Five species of Ceutorhynchitae were known from the Oligocene. One species of Phytobiini is described from the middle Oligocene of Germany (Theobald, 1937; Legalov, 2015). Three species are known from the lower Oligocene of France and one from the Latest Oligocene of Germany (Foerster, 1891; Heyden and Heyden, 1866). We have studied the descriptions and illustrations (Foerster, 1891) of "Ceutorhynchus" from Brunnstatt. These species are similar to the new species because of the rather thick 
rostrum, the anterior margin of pronotum not raised and the pronotum without tubercles on the sides, and may belong to the new genus. " $C$." fischeri Foerster, 1891 differs from the new species in a small body $(2.2 \mathrm{~mm})$, longer rostrum, and narrow elytra interstriae. "C." crassirostris Foerster, 1891 is easily distinguished by its small body size $(1.1 \mathrm{~mm})$. " $C$." obliquus Foerster, 1891 is also smaller $(2.3 \mathrm{~mm})$. To clarify the systematic position of these species, it is necessary to re-study the types. " $C$." funeratus Heyden \& Heyden, 1866 from Rott is similar to a typical Ceutorhynchus with a thin rostrum and the raised anterior margin of the pronotum. Only an elytron of Ceutorhynchitae is known from the Neogene of France (Piton and Théobald, 1935). This group has not been found in other Neogene localities (Legalov, 2015) and even lacks in the Dominican and Mexican Miocene amber with diverse weevil faunas (Legalov and Poinar, 2016; Poinar et al., 2016; Legalov, 2019; Legalov et al., 2019). Thus, in the Oligocene of Europe, representatives of two tribes are found, which are also recorded in the Eocene.

\section{Paleoecological remarks}

Here we report and figure a rare case of direct evidence proving that weevils of the subfamily Apioninae (Brentidae) were an important food item of the only fish species recorded from the paleolake Enspel, the cyprinid Palaeorutilus enspelensis (Böhme, 1996) Böhme, 2000. This is based on content preserved in its digestive tract (Fig. 3a-b). Furthermore, coprolites packed with weevil remains were also recorded (Fig. 3c). This trophic relationship has been remarked previously (Böhme and Wedmann, in Böhme, 1996) and is in line with functional morphological evidence relating to the form of the jaw bones of this fish, which probably foraged for insects floating at the water surface (Böhme, 1996). The relative abundance of weevil remains in those coprolites may be due to the food preference of Palaeorutilus enspelensis, to preservational factors relating to their robust exoskeleton, or it may as well reflect an extraordinary abundance of weevils in the Enspel paleoecosystem. The latter explanation is backed by the finding that the Enspel insect taphocoenosis in general is numerically strongly dominated by weevils, bibionid Diptera, and ants (Wedmann, 2000; Wedmann et al., 2010). It is furthermore possible to infer an aquatic or semiaquatic lifestyle for the Apioninae (and perhaps other weevil taxa) represented in the coprolites. This intriguing hypothesis cannot, however, be substantiated at present.

Data availability. All material included in the paper is deposited in the Landessammlung für Naturkunde Rheinland-Pfalz at the Naturhistorisches Museum Mainz.
Author contributions. AAL wrote a first draft of the manuscript relating to description and taxonomy and prepared the drawing. MJP conducted field work, collected specimens, took the photographs, and wrote parts of the text. Both authors discussed results and prepared and approved the final manuscript.

Competing interests. The authors declare that they have no conflict of interest.

Acknowledgements. The authors thank Boris A. Korotyaev (Saint Petersburg, Russia) for the opportunity to study comparative material deposited in the Zoological Institute RAS. We thank Petra Schäfers and Kai Nungesser (both GDKE, Landesarchäologie/Erdgeschichte, Mainz) for curating the Enspel material.

Review statement. This paper was edited by Florian Witzmann and reviewed by Enzo Colonnelli and Vitalii Alekseev.

\section{References}

Alonso-Zarazaga, M. A. and Lyal, C. H. C.: A world catalogue of families and genera of Curculionoidea (Insecta: Coleoptera) (Excepting Scolytidae and Platypodidae), Entomopraxis, Barcelona, Spain, 1999.

Alonso-Zarazaga, M. A., Barrios, H., Borovec, R., Bouchard, P., Caldara, R., Colonnelli, E., Gültekin, L., Hlaváč, P., Korotyaev, B., Lyal, C. H. C., Machado, A., Meregalli, M., Pierotti, H., Ren, L., Sánchez-Ruiz, M., Sforzi, A., Silfverberg, H., Skuhrovec, J., Trýzna, M., Velázquez de Castro, A. J., and Yunakov, N. N.: Cooperative catalogue of Palaearctic Coleoptera Curculionoidea, Monografías electrónicas de la Sociedad Entomológica Aragonesa, Sociedad Entomológica Aragonesa, Zaragoza, Spain, 2017.

Anderson, R. S.: 131. Curculionidae Latreille 1802, in: American Beetles, Polyphaga: Scarabaeoidea through Curculionoidea, edited by: Arnett, R. H., Thomas, M. C., Skelley, P. E., and Frank, J. H., CRC Press, Boca Raton, USA, 722-815, 2002.

Arnoldi, L. V., Zaslavsky, V. A., and Ter-Miassian, M. E.: Fam. Curculionidae, in: Opredelitel' nasekomykh evropeiskoi chasy SSSR, edited by: Gur'eva, E. L. and Kryzhanovsky, O. L., Nauka, Moscow-Leningrad, 5, 485-621, 1965.

Böhme M.: Revision der oligozänen und untermiozänen Vertreter der Gattung Palaeoleuciscus Obrhelova, 1969 (Teleostei, Cyprinidae) in Mitteleuropa, $\mathrm{PhD}$ thesis, University of Leipzig, Germany, 103 pp., 1996.

Böhme, M.: Die Cypriniden (Teleostei: Cypriniformes) des oberoligozänen Maares von Enspel nebst Bemerkungen zur Phylogenie und Biogeographie der Phoxininae, Paläontol. Z., 74, 99112, 2000.

Brockhaus, T., Müller, O., Nel, A., Poschmann, M. J., and Wappler, T.: Fossil dragonflies (Odonata: Anisoptera) from the late Oligocene Fossil-Lagerstätte Enspel (RhinelandPalatinate, SW-Germany), Palaeoentomology, 3, 284-300, https://doi.org/10.11646/palaeoentomology.3.3.9, 2020. 
Cockerell, T. D. A.: Fossil arthropods in the British Museum, An. Mag. Nat. Hist., 9, 273-279, 1920.

Colonnelli, E.: Catalogue of Ceutorhynchinae (Insecta: Coleoptera: Curculionidae) of the world, with a key to genera, Argania editio, Barcelona, Spain, 2004.

Comte, B. and Vianey-Liaud, M.: Nouveau Eomyidae du Paléogène d'Europe occidentale, C. R. Acad. Sc. Paris, 304, serie 2, 951954, 1987.

Engesser, B. and Storch, G.: Eomyiden (Mammalia, Rodentia) aus dem Oberoligozän von Enspel im Westerwald (Westdeutschland), Eclogae Geol. Helv., 92, 483-493, 1999.

Fanti, F. and Poschmann, M.: First soldier beetles (Coleoptera Cantharidae) from the late Oligocene Enspel FossilLagerstätte (SW Germany), Palaeoentomology, 2, 363-371, https://doi.org/10.11646/palaeoentomology.2.4.10, 2019.

Felder, M., Weidenfeller, M., and Wuttke, M.: Lithologische Beschreibung einer Forschungsbohrung im Zentrum des oberoligozänen, vulkano-lakustrinen Beckens von Enspel/Westerwald (Rheinland-Pfalz; Bundesrepublik Deutschland), Mainzer geowiss. Mitt., 27, 101-136, 1998.

Fikáček, M., Hájek, J., and Prokop, J.: New records of the water beetles (Coleoptera: Dytiscidae, Hydrophilidae) from the central European Oligocene-Miocene deposits, with a confirmation of the generic attribution of Hydrobiomorpha enspelense Wedmann 2000, Ann. soc. entomol. Fr., 44, 187-199, 2008.

Foerster, B.: Die Insekten des "Plattigen Steinmergels" von Brunstatt, Abh. Geol., 3, 333-594, 1891.

Gaupp, R. and Wilke, A.: Zur Sedimentologie der oberoligozänen Seesedimente von Enspel/Westerwald, Hallesches Jahrb. Geowiss. B, 20, 97-118, 1998.

Germar, E. F.: Insectorum species novae aut minus cognitae, descriptionibus illustratae. Volumen primum. Coleoptera, Impensis J. C. Hendelii et filii, Halae, xxiv + 624 pp., 2 pls., 1823.

Gozis, M. des.: Notes et remarques pour le futur catalogue de la faune gallo-rhénane (2e série), Rev. Entomol., 4, 116-132, 1885.

Gültekin, L. and Colonnelli, E.: A new species of Mogulones from Northeastern Turkey, with revision of the abchasicus group (Insecta, Coleoptera: Curculionidae), Aldrovandia, 2, 15-22, 2006.

Hacet, N. and Colonnelli, E.: On the Ceutorhynchinae (Coleoptera: Curculionidae) fauna of Turkish Thrace, with additional records for Turkey, J. Entomol. Res. Soc., 21, 175-183, 2019.

Heyden, C. and Heyden, L.: Käfer und Polypen aus der Braunkohle des Siebengebirges, Palaeontographica, 15, 131-156, 1866.

Jessen, K.: New fossil ants of the subfamily Myrmicinae (Hymenoptera, Formicidae) from the Upper Oligocene of Enspel (Westerwald Mountains, Rhineland Palatinate, Germany), Palaeobio. Palaeoenv., 100, 1007-1045, https://doi.org/10.1007/s12549-019-00406-2, 2020.

Klebs, R.: Über Bernsteinschlüsse im allgemein und die Coleopteren meiner Bernsteinsammlung, Schr. Physikal.Ökonom. Ges. Königsberg, Russia, 51, 217-242, 1910.

Köhler, J. and Uhl, D.: Die Blatt- und Karpoflora der oberoligozänen Fossillagerstätte Enspel (Westerwald, Rheinland-Pfalz, WDeutschland), Mainzer Naturwiss. Archiv Beih., 35, 1-87, 2014.

Lawrence, J. F., Beutel, R. G., Leschen, R. A. B., and Slipinski, S. A.: Glossary of Morphological Terms, in: Handbook of Zoology. Arthropoda: Insecta, Tb. 40: Coleoptera (Beetles), Vol. 2: Morphology and Systematics (Elateroidea, Bostrichformia, $\mathrm{Cu}$ - cujiformia partim), edited by: Kristensen, N. P. and Beutel, R. G., Walter de Gruyter, Berlin/New York, 9-20, 2010.

Legalov, A. A.: New and little known weevils (Coleoptera: Curculionoidea) from the Paleogene and Neogene, Hist. Biol., 25, 59-80, https://doi.org/10.1080/08912963.2012.692681, 2013.

Legalov, A. A.: Fossil weevils (Coleoptera, Obrienioidea, Curculionoidea) from Mesozoic and Cainozoic, Paleontol. J., 49, 1442-1513, https://doi.org/10.1134/S0031030115130067, 2015.

Legalov, A. A.: New weevils (Curculionidae) in Baltic amber, Paleontol. J., 50, 970-985, https://doi.org/10.1134/S0031030116090057, 2016.

Legalov, A. A.: Annotated key to weevils of the world. Part 3. Subfamily Conoderinae (Coleoptera, Curculionidae), Ukrainian J. Ecol., 8, 494-503, 2018.

Legalov, A. A.: New species of weevils (Coleoptera, Curculionidae) in Dominican amber, Paleontol. J., 53, 511-521, https://doi.org/10.1134/S003103011905006X, 2019.

Legalov, A. A.: A review of the Curculionoidea (Coleoptera) from European Eocene ambers, Geosciences, 10, 1-74, https://doi.org/10.3390/geosciences10010016, 2020a.

Legalov, A. A.: Fossil history of Curculionoidea (Coleoptera) from the Paleogene, Geosciences, 10, 358, 1-50, https://doi.org/10.3390/geosciences10090358, 2020 b.

Legalov, A. A. and Poinar Jr., G.: A new species of the genus Anthonomus Germar, 1817 (Coleoptera: Curculionidae) in Mexican amber, Paleontol. J., 50, 986-990, https://doi.org/10.1134/S0031030116090069, 2016.

Legalov, A. A. and Bukejs, A.: A new genus of the tribe Ceutorhynchini (Coleoptera: Curculionidae) in Baltic amber, Entomol. Fennica, 29, 185-190, https://doi.org/10.33338/ef.77305, 2018.

Legalov. A. A., Nazarenko, V. Y., and Perkovsky, E. E.: A new species of the genus Homocloeus Jordan (Coleoptera: Anthribidae) in Miocene Mexican amber, Paleontol. J., 53, 56-61, https://doi.org/10.1134/S0031030119010040, 2019.

Marvaldi, A. E. and Lanteri, A. A.: Key to higher taxa of South American weevils based on adult characters (Coleoptera, Curculionoidea), Rev. Chil. Hist. Nat., 78, 65-87, 2005.

Mertz, D. F., Renne, P. R., Wuttke, M., and Mödden, C.: A numerically calibrated reference level (MP28) for the terrestrial mammal-based biozonation of the European Upper Oligocene, Int. J. Earth Sci. (Geol. Rundsch.), 96, 353-361, 2007.

Oberprieler, R. G., Marvaldi, A. E., and Anderson, R. S.: Weevils, weevils, weevils everywhere, Zootaxa, 1668, 491-520, 2007.

Penney, D. and Jepson, J. E.: Fossil insects. An introduction to palaeoentomology, Siri Scientific Press, Manchester, UK, 2014.

Pirrung, M., Büchel, G., and Jacoby, W.: The Tertiary volcanic basins of Eckfeld, Enspel and Messel (Germany), Z. dt. geol. Ges., 152, 27-59, 2001.

Piton, L. and Théobald, N.: La faune entomologique des gisements miopliocènes du Massif Central, Rev. Sci. Nat. Auvergne, 2, 181, 1935.

Poinar Jr., G., Brown, A. E., and Legalov, A. A.: First record of the genus Pseudopilolabus Legalov, 2003 (Coleoptera: Attelabidae) in Dominican amber, Foss. Rec., 19, 11-16, https://doi.org/10.5194/fr-19-11-2016, 2016.

Poschmann, M.: Köcherfliegen-Larvengehäuse (Trichoptera: Integripalpia) aus der Enspel-Formation (Oberoligozän) des Westerwaldes, Mainzer naturwiss. Archiv, 44, 61-70, 2006. 
Poschmann, M. and Wedmann, S.: Spinnen, Heuschrecken und Wasserwanzen aus dem Westerwald, Fossilien, 22, 234-241, 2005.

Poschmann, M., Schindler, T., and Uhl, D.: Fossillagerstätte Enspel - a short review of current knowledge, the fossil association, and a bibliography, Palaeobio. Palaeoenv., 90, 3-20, https://doi.org/10.1007/s12549-009-0017-1, 2010.

Prena, J., Colonnelli, E., and Hespenheide, H. A.: Conoderinae Schoenherr, 1833, in: Handbook of Zoology. Arthropoda: Insecta. Tb. 40: Coleoptera (Beetles), Vol. 3: Morphology and Systematics (Phytophaga), edited by: Leschen, R. and Beutel, R. G., Walter de Gruyter, Berlin/Boston, 577-589, 2014.

Reitter, E.: Fauna Germanica. Die Käfer des Deutsches Reiches. Nach der analytische Methode bearbeitet, V., K.G. Lutz, Stuttgart, 343 pp., 1916.

Schäfer, P., Schindler, T., Hottenrott, M., and Wuttke, M.: Westerwald, in: Stratigraphie von Deutschland IX, Tertiär, Teil 1, edited by: Deutsche Stratigraphische Kommission, Schriftenr. deutsch. Ges. Geowiss., 75, 355-375, 2011.

Schindler, T. and Wuttke, M.: Geology and limnology of the Enspel Formation (Chattian, Oligocene; Westerwald Mountains, W-Germany), Palaeobio. Palaeoenv., 90, 21-27, https://doi.org/10.1007/s12549-009-0014-4, 2010.

Schindler, T. and Wuttke, M.: A revised sedimentological model for the late Oligocene crater lake Enspel (Enspel Formation, Westerwald Mountains, Germany), Palaeobio. Palaeoenv., 95, 5-16, https://doi.org/10.1007/s12549-014-0178-4, 2015.

Schoenherr, C. J.: Curculionidum dispositio methodica cum generum characteribus, descriptionibus atque observationibus variis, seu Prodromus ad Synonymiae Insectorum, partem IV, Fridericum Fleischer, Lipsiae, x + [2] + 338 pp., 1826.

Scudder, S. H.: Tertiary Rhynchophorus Coleoptera of the United States, Mon. U.S. Geol. Survey, 21, 1-206, 1893.

Stankiewicz, B. A., Briggs, D. E. G., Evershed, R. P., Flannery, M. B., and Wuttke, M.: Preservation of chitin in 25-million-year-old fossils, Science, 276, 1541-1543, 1997.

Storch, G., Engesser, B., and Wuttke, M.: Oldest fossil record of gliding in rodents, Nature, 379, 439-441, 1996.

Théobald, N.: Les insectes fossiles des terrains oligocènes de France, Ann. Entomol. Soc. Am., 32, 1-473, 1937.

Thomson, C. G.: Skandinaviens Coleoptera, synoptiskt bearbetade. I, Berlingska Bocktryckeriet, Lund, 290 pp., 1859.
Wagner, H.: Über das Sammeln von Ceuthorrhynchinen. (Die Nährpflanzen, Lebensgewohnheiten und Erscheinungszeiten der deutschen Ceuthorrhynchinen.) (Schluss), Koleopt. Rundschau, 30, 125-142, 1944.

Wappler, T. and Heiss, E.: Flatbugs from Paleogene limnic sediments. III. Enspel (Heteroptera: Aradidae), Zeitschr. Arbeitsgem. österreichischer Entomol., 58, 39-44, 2006.

Wedmann, S.: First records of fossil tremecine hymenopterans, Palaeontology, 41, 929-938, 1998a.

Wedmann, S.: Taphonomie der Bibionidae (Insecta: Diptera) aus der oberoligozänen Fossillagerstätte Enspel (Deutschland), N. Jb. Geol. Paläont. Mh., 1998, 513-528, 1998 b.

Wedmann, S.: Die Insekten der oberoligozänen Fossillagerstätte Enspel (Westerwald, Deutschland): Systematik, Biostratinomie und Paläoökologie, Mainzer naturwiss. Archiv, Beih., 23, 1-153, 2000.

Wedmann, S., Poschmann, M., and Hörnschemeyer, T.: Fossil insects from the Late Oligocene Enspel Lagerstätte and their palaeobiogeographic and palaeoclimatic significance, Palaeobio. Palaeoenv., 90, 49-58, https://doi.org/10.1007/s12549-0090013-5, 2010.

Wickham, H. F.: New fossil Coleoptera from the Florissant beds, Bull. Lab. Nat. Hist. Iowa, 7, 3-19, 1916.

Wuttke, M., Uhl, D., and Schindler, T. (Eds.): Fossil-Lagerstätte Enspel - exceptional preservation in an Upper Oligocene maar, Palaeobio. Palaeoenv., 90, 1-98, https://link.springer.com/ journal/12549/volumes-and-issues/90-1 (last access: 19 November 2020), 2010.

Wuttke, M., Schindler, T., and Smith, K. T. (Eds.): The Fossil-Lagerstätte Enspel - reconstructing the palaeoenvironment with new data on fossils and geology, Palaeobio. Palaeoenv., 95, 1-147, https://link.springer.com/journal/12549/ volumes-and-issues/95-1 (last access: 19 November 2020), 2015.

Zherikhin, V. V. and Egorov, A. B.: Zhuki-dolgonosiki (Coleoptera, Curculionidae) Dal'nego Vostoka SSSR (obzor podsemeistv s opisaniem novykh taksonov) [Weevils (Coleoptera, Curculionidae) from Russian Far East (review of subfamilies with description of new taxa)], Biologo-Pochvennyy Institut, Vladivostok, Russia, 164 pp., 1991. 